\title{
Katarzyna Kupczyk
}

Uniwersytet Ekonomiczny we Wrocławiu

e-mail: katarzyna.kupczyk@ue.wroc.pl

\section{PRZYSZLE MODELE BIZNESOWE NA RYNKU MEDIÓW 4.0 \\ FUTURE BUSINESS MODELS ON MEDIA 4.0 MARKET}

DOI: $10.15611 / \mathrm{e} 21.2017 .4 .05$

JEL Classification: M21, M29

Streszczenie: Celem artykułu jest przedstawienie prawdopodobnych przyszłych modeli biznesowych w ramach nowych możliwości uzyskiwania przychodów przez podmioty z sektora medialnego. W zakresie metodologicznym posłużono się analizą najnowszych dostępnych materiałów poświęconych tej tematyce, w tym przede wszystkim artykułów naukowych oraz opracowań pochodzących z renomowanych międzynarodowych instytucji badawczych i firm konsultingowych. Uzupełniają je obserwacje autorki, która była zawodowo związana z rynkiem mediów. Z prowadzonych rozważań wysnuto wniosek, iż immanentną cechą przyszłych modeli na rynku Mediów 4.0 będzie hybrydowość przekazu informacji.

Słowa kluczowe: biznes medialny, nowe media, Media 4.0.

Summary: The aim of the paper is to present possible future business models in terms of new opportunities for gaining incomes by media entities. For that purpose, there were discussed features of entities from Media 4.0 area, their further development opportunities and completely new phenomena - media products. Future business models and models in terms of gaining incomes will be based on many storages. In terms of methodology, the analysis of the newest available materials about that topic was used - including among others research papers and studies made by renowned international research institutes and consulting companies. They are refilled by conclusions of the author, who was professionally associated with the media market. In that context, the author wants to underline, that many phenomena in that sphere are new and, therefore, they have not been analyzed yet.

Keywords: media business, new media, Media 4.0.

\section{Wstęp}

Współczesna rzeczywistość naznaczona jest niezwykle dynamicznymi i często nielinearnymi zmianami w wielu obszarach życia. Jednym z takich obszarów jest segment szeroko pojętego biznesu medialnego. Sektor ten od dawna bazował na wielu 
najnowszych zdobyczach techniki, można więc powiedzieć, że jego rozwój ściśle zależał od rozwoju technik w obszarze gromadzenia, magazynowania i wysyłania informacji.

Obecnie media w coraz większym stopniu opierają się na nowych technologiach, sieciowości i podlegają silnemu ucyfrowieniu. Implementując do swoich modeli biznesowych technologie cyfrowe, takie jak platformy w formie chmury, duże zbiory danych, Internet Rzeczy czy wirtualna rzeczywistość, podmioty medialne przechodzą w kierunku tzw. Mediów 4.0. Pojęcie to wywodzi się z koncepcji Przemysłu 4.0, odnoszącej się do kolejnej, czwartej już fazy rozwoju produkcji i automatyzacji przemysłu prowadzącej do całkowitej cyfryzacji. W koncepcji tej położono nacisk na konieczność orientacji podmiotów na odbiorcę między innymi przez marketing internetowy, media społecznościowe oraz doświadczenie użytkownika. Media 4.0 stanowią formę ewolucyjnego przejścia z mediów tradycyjnych do mediów nowych, wykorzystującą postęp techniczny i wynikającą z niego, a jednocześnie otwierającą nowe możliwości w zakresie pełnego łańcucha obiegu informacji, tzn. od miejsca jej pierwotnego stworzenia do miejsca ostatecznej konsumpcji - wykorzystania, ze wszystkimi fazami - etapami pośrednimi [Kagermann i in. 2016, s. 16-34].

Media w kierunku poziomu 4.0 przechodzą także w Polsce i jest to proces zapoczątkowany całkiem niedawno. Należy przy tym podkreślić, że zarówno w kraju, jak i na świecie arbitralne wyznaczenie granicy pomiędzy mediami przeszłości i teraźniejszości a mediami przyszłości - Mediami 4.0 - jest niemożliwe. Jest to mianowicie nie nagła rewolucja z dnia na dzień zmieniająca struktury, organizacje, strategie, reguły gry, zasoby, ale ewolucyjnie dokonujący się proces, przebiegający z różnym natężeniem, w różnych obszarach, w różnym czasie. Właśnie takie zagadnienia zachęciły autorkę do zajęcia się tą tematyką.

W związku z postępującą cyfryzacją w branży medialnej oraz rozwojem nowych mediów modele biznesowe podmiotów medialnych będą wymagały przeobrażenia. Celem artykułu jest przedstawienie prawdopodobnych przyszłych modeli biznesowych w obszarze nowych sposobów uzyskiwania przychodów przez podmioty $\mathrm{z}$ tego sektora. $\mathrm{W}$ tym celu omówione zostały cechy podmiotów działających na rynku Mediów 4.0, ich dalsze możliwości rozwojowe oraz zupełnie nowe zjawiska - produkty medialne. Przyszłe modele biznesowe oraz modele w zakresie uzyskiwania przychodów bowiem będą się opierać na wielu składowych.

Zastosowane metody badawcze to przede wszystkim analizy najnowszych dostępnych materiałów poświęconych tej tematyce, w tym przede wszystkim artykułów naukowych oraz opracowań pochodzących z uznanych międzynarodowych instytucji badawczych i firm konsultingowych. Uzupełniają je wnioski własne autorki, która była zawodowo związana z rynkiem mediów. W tym kontekście autorka pragnie zwrócić uwagę, iż wiele zjawisk zachodzących w tej sferze jest nowych i w związku z tym dotychczas rzadko poddawanych naukowej analizie. 


\section{Zalożenia wstępne}

Przez lata biznes medialny miał jeden ze swoistych quasi-monopoli na przekazywanie informacji. Rewolucja technologiczna w latach 90. XX wieku spowodowała jednak, że tę pozycję utracił. Zniknęło wiele wcześniejszych barier wejścia, a komercjalizacja internetu jako pełnoprawnego medium - następnego kanału przekazywania informacji - spowodowała, iż zawód dziennikarza przestał być, jak niegdyś, zawodem elitarnym, zastrzeżonym dla nielicznych. Dziś właściwie każdy zaczynający działalność paramedialną zaczyna być dziennikarzem. W tym kontekście internet stworzył podwaliny dla funkcjonowania nowej rzeczywistości medialnej i wobec tego dla przyszłego funkcjonowania Mediów 4.0. Jednakże, będąc jako podwaliną, strukturą technologiczną - harware'ową do funkcjonowania Mediów 4.0, bez której nie mogłyby one w ogóle istnieć, internet stworzył całkowicie nowe możliwości przekazu informacji z usprawnionym wykorzystaniem dotychczas istniejących kanałów jej przepływu.

Media 4.0 są zjawiskiem nowym, które dopiero zaczyna kształtować naszą rzeczywistość [Lytle 2013, s. 53-84]. W związku z tym trzeba zaznaczyć, że obecnie niezwykle trudno jest wskazywać na przyszłość tego sektora. W tym kontekście poniższe rozważania nie wyczerpują kwestii przybliżenia tego zagadnienia, a raczej stanowią pewien fundament do przygotowywania nowych opracowań w przyszłości. Zagadnienie dotyczy zatem głównie tego, jak będzie przebiegać w przyszłości komercjalizacja nowych produktów i usług w tym sektorze, bezpośrednio wpływająca na jego szanse wzrostu i rozwoju w przyszłości. Trzeba podkreślić, że kierunki i natężenie tego wzrostu i rozwoju w określonych obszarach determinować będą możliwości i sposób funkcjonowania sektora. Obecnie tworzone są zatem fundamenty dla procesów i zjawisk, jakie z większym natężeniem wystąpią dopiero w przyszłości, niewykluczone, że już tej nieodległej.

Nowe technologie dadzą przede wszystkim możliwość bardzo szeroko i głęboko posuniętej indywidualizacji w dostarczaniu informacji. Wielkim problemem dzisiejszego społeczeństwa jest życie w środowisku nadinformacji. Ludzie są przytłoczeni nadmiarem spływających danych i wiadomości, których nie są w stanie poznać, ocenić, przyswoić i wykorzystać. To powoduje, że wielokrotnie mogą nie zapoznawać się z informacjami dla nich naprawdę ważnymi, gdyż nie są w stanie do nich dotrzeć, przebijając się przez tzw. śmieci informacyjne, co okazuje się bardzo czasochłonne i pracochłonne. Tymczasem Media 4.0 teoretycznie, w oparciu o już ujawnione preferencje w sieci, jednocześnie uwzględniając nowe preferencje, są w stanie dostarczyć tę informację, której wymaga dany odbiorca, jako pierwszą bądź w ogóle jedyną ${ }^{1}$. Poszerzanie zindywidualizowania dostarczanych informacji oznacza tutaj przekazywanie jednemu odbiorcy zindywidualizowanych informacji z różnych źródeł i na wiele tematów. Natomiast pogłębianie dostarczanej informacji określa

\footnotetext{
${ }^{1}$ Oparto na: [https://www.fau.eu/2016/10/24/news/research/from-industry-4-0-to-publishing-4-0/].
} 
zawartość danej informacji, czyli tego, ile zawiera ona danych na temat określonego zjawiska. Odbiorca mianowicie będzie mógł sam aktywnie i elastycznie wybierać, czy w danym momencie interesuje go informacja podstawowa, czy też poszukuje informacji o większej zawartości.

Należy również wskazać, że Media 4.0 zaczynają stanowić swoiste remedium na problem nadprodukcji informacji, jaki pojawił się w ostatnich latach. Innymi słowy, stanowią jedno z możliwych rozwiązań na ponowne stworzenie symetrii pomiędzy produkcją i odbiorem informacji. Wraz z rewolucją, która dokonywała się od lat 90. na rynku medialnym, doszło bowiem do powstania bardzo niebezpiecznej asymetrii, nadpodaży informacyjnej - zatłoczenia informacją, której odbiorcy nie byli w stanie przetworzyć.

\section{Przyszle modele biznesowe na rynku Mediów 4.0}

Przyszłe modele biznesowe wdrażane przez podmioty działające zgodnie ze strategią Mediów 4.0 będą otwarte, sieciowe i oparte na analizie danych [Albarran 2017, s. 21-26]. Ponadto integrować będą wiele różnych modeli przychodów biznesowych. Powyższe oznacza, że firmy będą dość swobodnie „poruszały się” pomiędzy istniejącymi modelami biznesowymi oraz strumieniami przychodów powiązanymi wzajemnie w coraz bardziej elastyczny sposób.

Przyszłe modele biznesowe oprą się też na kompleksowych kontraktach, porozumieniach i warunkach świadczenia usług. Ponadto będą musiały pozostawać zgodne ze zbiorem zasad narzuconych przez zaledwie kilku gigantów formujących specyficzny ekosystem w cyfrowo połączonym świecie. Podmioty te określane są także jako GAFA, co stanowi akronim utworzony z pierwszych liter ich nazw Google, Apple, Facebook, Amazon. To właśnie te podmioty, poprzez zogopolizowanie rynku, realnie określają zasady jego funkcjonowania, gdyż skala i zakres ich oddziaływania na ten rynek jest tak duża, że inni gracze muszą podporządkować się tworzonym przez nich rozwiązaniom i platformom, aby w ogóle móc swobodnie na tym rynku funkcjonować [Noam 2016, s. 1180-1243]. Powoduje to powstanie dwubiegunowego układu sił, w którym zaledwie kilku graczy określa warunki gry dla wszystkich pozostałych. Mogą to uczynić wskutek posiadania naturalnie powstałej quasi-monopolistycznej przewagi, wytwarzanej przez lata dzięki przewadze technologicznej oraz koncepcyjnemu i produktowemu liderowaniu w określonych obszarach rynku medialnego [Media 2020. A Universe... 2014, s. 11-12].

$\mathrm{W}$ rezultacie małe podmioty w bardzo krótkim czasie, dzięki umiejętnemu połączeniu wzrostu realizowanego autonomicznie z akwizycjami, były w stanie osiągnąć rozmiary, które z rynku medialnego podzielonego pomiędzy wielu graczy uczyniły rynek tak niezrównoważony. Było to również możliwe, ponieważ regulacje prawne w zakresie kształtowania systemu mediów cyfrowych następowały z bardzo dużym opóźnieniem w stosunku do realnej sytuacji na rynku, tym bardziej, że tzw. pisane i niepisane zasady cyfrowego ekosystemu medialnego mogą i najprawdopodobniej 
będą mogły być w dalszym ciągu zmienione w ciągu jednej nocy. W bardzo zasadniczy sposób wpłynie to na warunki świadczenia usług, prawa publikacji, rozpowszechnianie i kontrakty na płatności stosowane na całym świecie.

Przyszłe modele biznesowe oraz modele w zakresie uzyskiwania przychodów będą się opierać na następujących składowych [Eurotransmedia Vision Document... 2015, s. 30-32]:

- podziale źródeł uzyskiwania przychodu, tzw. revenue share. Oznaczać to będzie, że posiadacze poszczególnych platform będą dzielili się przychodem z dostawcami rozwiązań dostępnych na tych platformach. Dobrym przykładem takiego podziału jest platforma Apple App Store - przychód rozdysponowywany jest pomiędzy wszystkich, którzy dystrybuują i publikują treści;

- modelach subskrypcyjnych - warto podkreślić, że tradycyjne modele oparte na prenumeracie, choć wywodzą się ze starego modelu funkcjonowania mediów, w dalszym ciągu będą utrzymane w erze postępującej cyfryzacji. Modele te są mianowicie bardzo pozytywnie oceniane;

- modelach freemium - w modelach tych pewna zawartość jest dostępna za darmo, jednakże, jeśli użytkownik chce mieć pełen dostęp do treści i ewentualnych dodatków, musi wykupić abonament;

- modelach crowdsourcingowych - oznaczających wcześniejsze finansowanie treści poprzez przedsprzedaż bezpośrednio do odbiorcy;

- modelach „płać i korzystaj”;

- modelach „wypróbuj i zapłać”;

- modelach zbierania danych - użytkownik musi podać swoje dane, aby dostać dostęp do treści;

- modelach płatności za wykorzystanie albo za wydrukowanie.

Do tej grupy należy dodać także inne, nowe modele, które nie są jeszcze skomercjalizowane.

Jednym z kluczowych elementów strategii w ramach modeli biznesowych Mediów 4.0 będzie tzw. opowieść transmedialna, tzn. „wielowątkowa i zróżnicowana historia, która prezentowana jest na różnych platformach medialnych" [Jenkins 2008, s. 260]. Pojęcie to jest związane ze zjawiskiem konwergencji mediów, polegającym między innymi na pogłębianiu się współpracy oraz coraz silniejszym przenikaniu się odmiennych mediów. W wyniku tego następuje cyrkulacja treści sprawiająca, że jedna historia zostaje opowiedziana wielokrotnie za pomocą różnych środków przekazu. W związku z tym coraz ważniejszymi graczami na rynku medialnym będą dostawcy łączności i sieciowości, zawierający coraz więcej umów na temat wspólnego udostępniania treści dostarczanych przez poszczególnych graczy na jednolitych platformach. Platformy te są i będą tworzone przez podmioty kilku kategorii [2016 Entertainment... 2016, s. 5-16]:

- Do pierwszej należą główni gracze rynku telefonii cyfrowej, którzy posiadają własną infrastrukturę przesyłania danych i w oparciu o nią są w stanie tworzyć kompletne platformy medialne. Doskonałym przykładem są tu działania podej- 
mowane przez takie podmioty, jak Deutche Telekom, Vodafone, Orange i Telenor oraz dostawców takich jak Netflix, HBO i Spotify.

- Druga grupa obejmuje czterech amerykańskich graczy określanych jako GAFA, o których była mowa wcześniej. Zaczynali oni w różnych sferach przestrzeni internetowej: Google jako wyszukiwarka internetowa, Facebook jako serwis społecznościowy, Apple jako dostawca komputerów i oprogramowania oraz Amazon jako sklep internetowy. Z czasem wytworzyli jednak specyficzne multiplatformy łączące wiele elementów i rozwiązań.

- Trzecia grupa obejmuje dostawców urządzeń oraz rozwiązań systemowych do nich. W grupie tej najbardziej charakterystyczne są dwa podmioty - koncern Sony ze swoimi odbiornikami telewizyjnymi, sektorem przemysłu filmowego i konsolą Play Station oraz Microsoft z systemem operacyjnym Windows i konsolą Xbox. Wszyscy ci gracze są niepodważalnie głównymi rozgrywającymi cyfrowej rzeczywistości od momentu, gdy użytkownicy potrzebują oferowanych przez nich dóbr w celu uzyskania dostępu do produktów medialnych.

Cechą biznesu medialnego i jego ekonomii będzie także specyfika właścicieli marek oraz praw własności intelektualnej - zarówno z tzw. świata rzeczywistego, jak i świata cyfrowego. Te elementy będą miały coraz większe znaczenie w przyszłych modelach biznesowych. Ich cechą będzie to, że - zamiast pełnienia funkcji prostych produktów dostarczanych przez zwykłych producentów - będą włączane w coraz bardziej zespolone platformy.

Ponadto cechą znamienną będzie fakt włączenia w produkcję transmediów różnych wydawców, agregatorów oraz przedstawicieli handlu internetowego (tzw. e-commerce) działających na dużą skalę [The Future of the Transmedia... 2016, s. 6-12].

Nowe modele biznesowe będą też oznaczać zmianę możliwości finansowania. $\mathrm{W}$ przeszłości w finansowaniu takim, a szczególnie w finansowaniu dużych projektów, występowało bowiem sporo ograniczeń charakteryzowanych jako zbyt wiele zagrożeń, zbyt wiele pracy, przy jednocześnie bardzo niskich budżetach. Niemniej w nadchodzących latach w tej części biznesu da się wydzielić kilka powiązanych ze sobą procesów. Przede wszystkim pojawią się specjalne budżety, w jakie zaangażowane będą wszystkie strony. Techniczne możliwości odbioru przez odbiorcę zindywidualizowanych treści, z jednoczesnym dokładnym śledzeniem przez niego poboru konkretnych treści o konkretnej zawartości w konkretnym czasie, spowodują ułatwienie w znajdowaniu dobrych modeli wewnętrznego rozliczania pomiędzy dostawcami tych treści, które odbiorca pobiera. Jeśli przyjmie się, że w przyszłym modelu Mediów 4.0 występować będzie zaledwie kilka platform, które w sposób kompletny i kompleksowy, a jednocześnie zintegrowany będą dostarczały treści od różnych dostawców, to $\mathrm{w}$ połączeniu $\mathrm{z}$ możliwością analizy pobieranych danych, odbieranych przez konkretnego użytkownika, da to możliwość przygotowania nowych modeli finansowania. Już obecnie system jest w stanie dokładnie przeanalizować treść pobieraną przez użytkownika w czasie rzeczywistym. W modelu Mediów 
4.0 użytkownik będzie pobierał tę treść w sposób wybitnie zindywidualizowany². Naliczana mu opłata również będzie indywidualna. To znaczy, że użytkownik będzie płacił za każdą specyficzną treść pobieraną z danej strony, ewentualnie, jeśli algorytm będzie inny, odbiorca będzie wnosił opłatę w formie jednolitego, zintegrowanego pakietu płatności, a ta opłata będzie już następnie rozdzielana proporcjonalnie pomiędzy wszystkich dostawców treści.

Należy przypuszczać, iż na takim rozwiązaniu zyskają zarówno dostawcy treści, jak i użytkownicy. Dla użytkowników korzyści będzie kilka. Po pierwsze, na jednolitej platformie odbiorca będzie miał dostęp do wielu treści dostarczanych przez różne podmioty. Nie będzie więc musiał szukać interesujących go treści na różnych stronach, bo znajdzie je na jednej. Po drugie, będzie dokonywał jednej płatności za zintegrowany dostęp do jednej platformy, a nie wielu płatności za oddzielny dostęp do każdej ze stron. Po trzecie, całkowita opłata, jaką wniesie, będzie niższa niż suma wszystkich opłat, jakie wnosiłby oddzielnie. Dla dostawców informacji zaś korzyścią będzie to, że uzyskają łatwiejszy dostęp do większej grupy użytkowników. W związku z tym tańszy dostęp użytkowników do zawartości danej platformy będzie kompensowany większą liczbą wejść odbiorców.

Ponadto do zalet tego systemu zaliczać się będzie to, że pozwoli on na bardzo elastyczny dobór treści oraz płatność wyłącznie za treści interesujące konkretnego użytkownika. W dzisiejszych rozwiązaniach często mianowicie bywa tak, że użytkownik płaci za dostęp do całej platformy, czyli za treści zarówno go interesujące, jak i nieinteresujące. W modelu Mediów 4.0 odbiorca będzie płacił wyłącznie za treści, które go interesują. $\mathrm{Z}$ drugiej jednak strony, będzie to stanowiło pewne wyzwanie dla strony podażowej. Nieraz bowiem zachodzi sytuacja, że wejścia na jedne, bardziej popularne treści generują przychody umożliwiające publikację treści bądź stron mniej popularnych, ale utrzymywanych przez wydawcę przykładowo ze względów prestiżowych. Tak między innymi funkcjonują prenumeraty współczesnych gazet - najwięcej obrotów generują informacje związane z sensacją, polityką, a najmniej z kulturą. W modelu Mediów 4.0 będzie tymczasem następowało silne przechodzenie nie na dostęp do platformy jako całości, ale na dostęp do konkretnej, celowanej informacji dla konkretnego użytkownika w danych warunkach. W związku z tym modele biznesowe działania Mediów 4.0 będą się wiązały ż:

- tworzeniem specyficznych budżetów, elastycznie dopasowywanych do zmieniających się warunków,

- wchodzeniem różnych producentów na określone platformy i rezygnowaniem $\mathrm{z}$ nich,

- poszukiwaniem zwielokrotnienia zysków i generowania obrotów poprzez elastycznie kształtowaną współpracę, z jednej strony pomiędzy dostawcami infor-

2 Oparto na: [http:/www.pubiz.de/home/management/management_artikel/datum/2016/10/14/ publishing-40-konsequente-kundenorientierung-ist-der-kern.htm].

${ }^{3}$ Jak wyżej. 
macji, z drugiej pomiędzy platformą jako nośnikiem skomasowanej informacji a odbiorcami tychże informacji,

- porozumieniami o współpracy pomiędzy producentami informacji a twórcami platform oraz dostawcami informacji do indywidualnego użytkownika w zakresie właściwego podziału wypracowanych zysków,

- redefinicją wskaźnika ROI, który będzie musiał uwzględniać wszystkie wyżej wymienione elementy,

- stale zwiększającą się liczbą wielopłaszczyznowych projektów, które będą ukierunkowane na permanentne zwiększanie swojego wpływu i zasięgu. Procesy te będą się dokonywać od poziomu podmiotów związanych z biznesem komunikacyjnym poprzez przemysł medialny, który będzie musiał proponować coraz bardziej łączoną i mieszaną zawartość, kończąc na sektorach niemedialnych, które każdego dnia w stale wzrastającym stopniu podlegają ucyfrowieniu.

Wszystkie te działania są ukierunkowane na stworzenie nowych możliwości do rozwoju biznesu.

Poza tym telewizja, sztuczna inteligencja oraz wirtualna rzeczywistość, dzięki swojemu potencjałowi, przyczynią się do dostarczania odbiorcom nowych doświadczeń [Transmedia Storytelling... 2016, s. 2-6]. Środowiska 360-stopni i innowacyjne platformy scenariuszowe zrewolucjonizują branże filmów animowanych, dokumentalnych oraz życie codzienne. W takim układzie sukces rozwoju technologii będzie coraz bardziej zależny od jej akceptacji przez użytkowników oraz jej „przejrzystości” - użytkownicy wymagają bowiem mało skomplikowanej obsługi i funkcjonalności, które nie spowalniają pracy urządzeń.

Chociaż rozwój transmediów będzie się dokonywał kosztem ochrony lokalnych i kulturowych treści, stanowi dużą szansę dla współczesnego biznesu medialnego. Media przyszłości oznaczają mianowicie tworzenie światowych społeczności, których konsumpcja nie będzie uzależniona od barier kulturowych, ale będzie się raczej opierać na „wszechświatach fikcyjnych i twórczych”. Ponadto z dnia na dzień coraz bardziej ucyfrowione stają się nowe sektory, takie jak opieka zdrowotna, styl życia oraz konsumpcja niemedialnych usług i towarów. To połączenie pomiędzy sektorami cyfrowymi a innymi sektorami - społecznym, przemysłowym lub gospodarczym - już dziś stanowi szansę biznesową dla treści medialnych. Jednocześnie wiele tradycyjnych sektorów zmierza w stronę mediów poprzez działania w ramach tzw. Marketingu 4.0. To obszar, w którym występuje najwięcej treści medialnych [Zerdick i in. 2012, s. 18-27].

W takim zmieniającym się środowisku, w którym tradycyjni producenci treści są w dużym stopniu wspierani przez władze publiczne, producenci mediów będą coraz częściej inwestować w sektor prywatny. Dlatego wspieranie tworzenia innowacyjnych narzędzi finansowych powinno stanowić kluczowy element rozwoju przemysłu mediów. W przyszłości bowiem powinny ewoluować jeszcze potężniejsze i bardziej wpływowe narzędzia, takie jak platformy crowdfundingowe, czyli forma finansowania różnego rodzaju projektów przez społeczność, która jest lub zostanie wokół 
tych projektów zorganizowana [Ordanini i in. 2011, s. 12-17]. Dzisiaj stanowią one podstawowy element nowej gospodarki cyfrowej do tworzenia treści medialnych.

Tworzenie treści dla kilku mediów jednocześnie jest zupełnie nowym wyzwaniem, a kreacja jednorodnego, fikcyjnego i twórczego wszechświata, który jako całość utworzy „wyższą” treść na kilku różnych urządzeniach, wymaga specyficznej wiedzy oraz odpowiednich kompetencji.

\section{Zakończenie}

$\mathrm{Z}$ całą pewnością przechodzenie mediów w kierunku poziomu określanego obecnie jako Media 4.0 będzie się wiązało z rozpoczęciem całkowicie nowego etapu w ich funkcjonowaniu. Media 4.0 narodziły się dzięki rewolucji technologicznej, ale ta sama rewolucja spowoduje, że ludzie w coraz większym stopniu będą żyli w środowisku nadinformacyjnym - natłoku informacji, a informacje medialne będą się przenikać i istnieć obok innych informacji. Czym więc będzie się różniła wiadomość tekstowa wysłana przez znajomego na temat pewnego zdarzenia od wiadomości o analogicznym zdarzeniu wysłanej przez serwis informacyjny? Jeśli mianowicie obie dotyczą tego samego zdarzenia, to co czyni jedną informację medialną, a drugą nie? Obecnie tę różnicę da się jeszcze wyszczególnić, lecz ma to wyłącznie charakter formalnoprawny, a nie funkcjonalno-użytkowy. Kwestia dotyczy tego, że za informację medialną uważa się informację, która została wygenerowana przez podmioty prawnie funkcjonujące jako media, co w polskim przypadku wiąże się ze spełnianiem przez nie m.in. wymogów ustawy z 1994 roku. W rzeczywistości jednak, z punktu widzenia odbiorcy, czyli w aspekcie funkcjonalno-użytkowym, ta informacja spełnia tę samą funkcję.

W związku z tym należy sformułować następujące wnioski. Immanentną cechą Mediów 4.0 będzie hybrydowość przekazu informacji. Informacja będzie bowiem wygenerowana od razu w sposób, który umożliwi jej transmisję poprzez różne kanały. To z kolei będzie powodować, że informacja będzie musiała mieć budowę modułową i nadawać się do jednoczesnego przesyłu za pomocą oddzielnie wizji, fonii, połączonej wizji i fonii oraz kanałów opartych na sensualności, w których odbiorca zostanie aktywnie włączony w odbiór tej informacji. W takim układzie informacja będzie istniała nie obok odbiorcy, lecz razem z nim. W tę informację zostanie włączony nie tylko umysł, ale też i ciało. Konkretną informację będzie się nie tylko poznawać, ale być może i docelowo również przeżywać, odczuwając takie same wrażenia, jakby się było aktywnym uczestnikiem zaistniałych wypadków. Powyższe z kolei będzie prowadziło do coraz silniejszego zacierania się granicy pomiędzy światem realnym a światem dotychczas nierzeczywistym, istniejącym wyłącznie w przestrzeni medialnej.

Jeśli zatem faktycznie Media 4.0 doprowadzą do zoptymalizowania w zakresie zindywidualizowania przekazywania informacji, przywrócą ponownie swoistą równowagę między podażą i popytem. System medialny, produkujący te informacje 
w nadmiarze, będzie jednocześnie je samodzielnie selekcjonował. Dlatego jeśli rzeczywiście te procesy zajdą, to Media 4.0 mogą spowodować, że do odbiorców realnie zacznie docierać więcej przyswajalnej przez nich informacji, ponieważ nie będą oni tracili czasu i sił na poszukiwanie, a czas dotychczas poświęcony będą mogli spożytkować tylko i wyłącznie na dogłębne zapoznanie się z informacją ich interesującą. Ponadto należy wskazać, że eklektyzm tego systemu może jednocześnie nie wykluczać przekazywania innych informacji nawet w formie skrótowej, mimo że pierwotnie informacje te nie zostały przez odbiorcę wyspecyfikowane.

Jednocześnie przyszły kształt sektora w znacznym stopniu realnie określi i zdeterminuje strona popytowa - wszyscy ludzie żyjący w coraz bardziej powiązanym, sieciowym otoczeniu. Niemniej im bardziej ta sieć oplata, tym większy może narastać protest przeciwko niej. Nie jest jednak pewne, czy w ogóle wystąpi. Ludzie bowiem mogą cenić swobodę i nie chcieć być włączeni do sieci, które w końcu same będą za nich decydować. Tym samym pewne wizje rozwoju wypadków, dotychczas prezentowane przez scenariusze filmów z gatunku science fiction, mogą się okazać rzeczywistością.

Ponadto dużym wyzwaniem dla Mediów 4.0 jest i w coraz większym stopniu będzie spadek lojalności użytkowników, głównie tych młodszych. Oznacza to, iż nie będą oni przywiązani do konkretnej marki czy produktu, a swoje preferencje będą zmieniać niezwykle szybko, nieraz pod wpływem impulsu, chwili w momencie, gdy ktoś w ich przekonaniu zaproponuje im coś ciekawszego. Tym samym wytwarzana przez podmioty z biznesu medialnego ewentualna przewaga będzie miała wybitnie nietrwały charakter. Nie będzie już można mówić o długookresowej przewadze danego wydawnictwa czy wydawcy w odniesieniu do całości prowadzonego przez niego biznesu czy wyłącznie pewnych jego składowych. Będzie to jedynie chwilowa przewaga dotycząca często mikrorynków i specyficznych produktów - i tam nadawcy będą musieli szukać nowych szans wzrostu i rozwoju. Będą to jednak tylko - jak wskazano - przewagi możliwe do uzyskania na krótko. W efekcie żaden wydawca nie będzie dominujący. Każdy z liczących się graczy oraz wielu mniejszych nadawców w danej chwili będzie posiadało swoje specyficzne przewagi. W dodatku będą to przewagi niezwykle zindywidualizowane - zawierające zindywidualizowane treści i dostarczane w sposób zindywidualizowany, gdyż istotne z punktu widzenia określonych grup odbiorców, czyli zazwyczaj odbierane niezwykle subiektywnie. W efekcie to wyłącznie od odbiorcy będzie zależeć, z jakiego proponowanego przez dostawców formatu medialnego zechce skorzystać.

\section{Literatura}

2016 Entertainment \& Media Industry Trends, PwC 2016, s. 5-16.

Albarran A., 2017, The Media Economy, New York, s. 21-26.

Eurotransmedia Vision Document 2030, European Union's Seventh Programme for Research, Technological Development and Demonstration 2015, s. 30-32. 
http:/www.pubiz.de/home/management/management_artikel/datum/2016/10/14/publishing-40-konsequente-kundenorientierung-ist-der-kern.html.

https://www.fau.eu/2016/10/24/news/research/from-industry-4-0-to-publishing-4-0/.

Jenkins H., 2008, Kultura konwergencji. Zderzenie starych i nowych mediów, Wydawnictwa Akademickie i Profesjonalne, Warszawa, s. 260.

Kagermann H. i in., 2016, Industrie 4.0 in a Global Context, German Research Center for Artificial Intelligence, s. 16-34.

Lytle A., 2013, Faith Formation 4.0. Introducing an Ecology of Faith in a Digital Age, March, s. 53-84. Media 2020. A Universe of Digital Opportunities, Roland Berger Strategy Consult-ants 2014, s. 11-12. Noam E., 2016, Media Concentration and Ownership around the World, Oxford University Press, s. $1180-1243$.

Ordanini A., Miceli L., Pizzetti M., Parasuraman A., 2011, Crowd-funding: Transforming customers into investors through innovative service platforms, Journal of Service Management, s. 12-17.

The Future of the Transmedia Ecosystem, 2016, Sungkyunkwan University, s. 6-12.

Transmedia Storytelling: Virtual Reality in Journalism, RIT School of Media Sciences 2016, s. 2-6.

Zerdick A. i in., 2012, E-Merging Media: Communication and the Media Economy of the Future, Berlin, s. 18-27. 